\title{
Bertel Nygaard
}

\section{G. Monrad's Political Manifesto from 1839}

\author{
English Summary
}

The first issue of Ditlev Gothard Monrad's Flying Political Papers, published in Copenhagen in 1839, may be regarded as a manifesto of the early Danish liberal movement in its struggle to overcome the existing absolutist conglomerate state in favour of a constitutional national state, a result gradually achieved with the constitution of 1849 and the national centralization of the ensuing years. Influenced by Hegelian political philosophy, Monrad regarded his own times as marked by a great historical crisis and transition, evincing the political acknowledgment of the 'people' and its national unity as the outcome of a long-term dialectical development towards a synthesis of order and liberty, with existing absolutism representing a historically necessary, though now obsolete, stage. Further strengthening of the nation and the state now implied the political involvement of the 'core of the people', i.e. the educated middle class, whose culture allegedly rendered it capable of representing the interests of the people as a whole. Thus, Monrad's liberalism was an ideological defence of the rule of a quite narrow social layer, a particular political reflection of an internationally conditioned transition to capitalist commodity production carried out in Denmark mainly via the state as an avenue between a dominantly agrarian production and the world market.

\section{Bertel Nygaard}

Ph.d. i historie, adjunkt ved Institut for Historie og Områdestudier, Aarhus Universitet. Har skrevet adskillige artikler om politiseringen af dansk offentligt liv op til 1848, herunder »De phantastiske forskruede Forestillinger. Introduktioner til socialisme og kommunisme i Danmark før 1848 «, »Civilisation, kamp og fremskridt i C.F. Allens Haandbog $i$ Fadrelandets Historie « og "Hegelianism in Politics: Denmark 1830-48 «, der er under udgivelse i henholdsvis Historisk Tidsskrift, Historie og Intellectual History Review.

KéK 107 (2009), 92-115 


\section{D.G. Monrads liberale manifest fra 1839}

»Frederik den Sjette gjorde Folket til Mennesker, Christian den Ottende vil gjøre det til Borgere ", bemærkede den unge teolog Ditlev Gothard Monrad (1811-87) håbefuldt i første nummer af sine Flypende politiske Blade, udgivet få uger efter Frederik den Sjettes død i december 1839. ${ }^{1}$ Med kongetro retorik og ved at undgå alt for skarpe eksplicitte markeringer af et 'jeg' eller et 'vi' over for et 'dem' søgte han at leve op til enevældens formkrav. Ikke desto mindre viser hans betydningsmættede sondringer mellem begreberne 'folk', 'menneske' og 'borger' i denne sætning, at han identificerede dette 'folk' som sin talerposition og forbandt det med en liberal politisk tankegang, hvis konklusion var behovet for at erstatte enevælden med et konstitutionelt monarki. I denne henseende talte hans Flypende politiske Blade, som en kritiker senere udtrykte det, »et Sprog ukendt her i Landet «. ${ }^{2}$

Flypende politiske Blade udkom i 1839-40 og, efter en kort pause, i 1842 , som i alt fem små pjecer på 35 sider og opefter. Deres dristighed vakte betragtelig opsigt og debat, og i 1840 lod enevældens myndigheder forfatteren tiltale og dømme for kritik af forfatningen, regeringsforanstaltninger og en fremmed magt. ${ }^{3}$ Især det første nummer sammenfattede, i karakteristisk beskeden form uden anden overskrift end tidsskrifttitlen, Monrads politiske udsyn koncist og handlingsorienteret, knyttet til den bredere danske liberale bevægelses kamp for en fri forfatning, der kom til udtryk i nye organer for en politisk offentlighed, dvs. liberale dagblade og selskaber. ${ }^{4}$

Monrads brug af begreberne 'folk', 'menneske' og 'borger' som led i en udviklingstanke antyder den enhed af historisk overgangserfaring, politisk filosofi, optimistisk fremtidsperspektiv og aktuel politisk oppositionel handling, der gør teksten som helhed på én gang analyserende og performativ. I denne henseende kan Flyvende politiske Blade, og som nævnt især det første nummer, betragtes som det tætteste, danske liberale kom på et modstykke til det 8 år yngre Manifest der kommunistischen Partei af Marx og Engels. ${ }^{5}$ Monrads manifest fra 1839 fastlagde de grundlæg- 
gende maksimer for den unge liberale oppositionsbevægelse i perioden op til junigrundloven ti år senere, hvori han som hovedforfatter fastslog grundrammerne for dansk politik efter enevælden.

Sammen med den liberale forfatningsbevægelse, som den unge Monrad indgik $i$, er hans virke og hans manifest fra 1839 af eftertiden hovedsagelig blevet set som en optakt til det parlamentariske demokrati og nationalstatstanken. ${ }^{6}$ Hermed har man imidlertid forbigået en række periodespecifikke, kontekstbestemte elementer og symptomatiske modsætninger, som vil kunne fremdrages ved en tættere begrebsanalyse. Denne artikel skal undersøge Monrads tekst ad sådanne veje ved at betragte den som et manifest, dvs. som en enhed af politisk-ideologisk helhedsytring og handling, undersøgt ved dens centrale begreber, hovedtanker og fremstillingsform i en historisk debat- og handlingskontekst. Denne analysestrategi åbner for en mindre lineær og mere kritisk forståelse af 'guldalderens' åndsliv, den fremvoksende politiske kultur, liberalismen, nationalismen, folkelighedsdyrkelsen og det parlamentariske demokratis fremvækst.

\section{Politisering, krisefornemmelse og forfatningsdebat}

Som forudsætning for analysen af Monrads manifest og dets umiddelbare begrebs- og idehistoriske kontekst er det nødvendigt at skitsere 1830'ernes politisering og de spændingsforhold, der fulgte med den, herunder forfatningsdebattens opblussen i 1839.

Monrads Flyvende politiske Blade var forfatterens første større sammenhængende politiske tekst og fulgte umiddelbart efter hans første markante politiske optræden overhovedet. I årevis havde han stået på sidelinjen af den omfattende politisering af det danske offentlige liv siden den europæiske revolutionsbølge i 1830-31 og Frederik den Sjettes kundgørelse af planerne om stænderforsamlinger. Denne politisering var især markeret ved fremvæksten af en liberal bevægelse med fordringer om trykkefrihed og forfatningsgaranteret politisk indflydelse til en folkevalgt forsamling. ${ }^{7}$ Da resultatet imidlertid blev stækkede stænderforsamlinger, provinsbaserede frem for nationale og rådgivende frem for lovgivende, og da regeringen søgte at komme den liberale presse til livs ved at indskærpe og stramme trykkefrihedslovgivningen, forstærkede det de liberales oppositionelle stilling, i Danmark som i andre dele af Europa. ${ }^{8}$

Med politiseringen af den offentlige debat udvikledes ikke blot nye foreninger og tidsskrifter, men også nye begreber og kampe om gamle begrebers betydning, herunder politisk-ideologiske betegnelser som 'liberal', 'konservativ' og 'radikal', samt forskellige udlægninger af, hvad f.eks. de positivt ladede begreber 'almenånd' (i modsætning til 'partiånd', 
‘egoisme’ o.1.), ‘dannelse’ og 'kultur’ indebar. Meget af dette var overført fra udlandet, især tyske, franske og engelske debatter.

Ud over liberale kritikker af enevælden og konservative forsvar for den bestående orden opstod efterhånden en modvilje mod politiseringen som sådan, især i digterkredse og navnlig udtrykt i miljøet omkring Heiberg, herunder Henrik Hertz og Søren Kierkegaard. De fandt, at politiseringen, i det mindste i sine aktuelle former, var en uegentlig form for menneskelig eksistens og stred mod de organiske helheder, som fandtes i kunsten, poesien, filosofien eller religionen. For så vidt kan deres standpunkt betegnes som antipolitisk. ${ }^{9}$

Både politiseringen, og kritikken af den, udtrykte en udbredt opfattelse af samtiden som krise og overgang. Mens eftertiden har betegnet perioden som 'guldalderen' på grund af den kunstneriske blomstring, betragtede samtidige iagttagere dog snarere deres tid som præget af det gamles forfald og overgangen til noget nyt, der var fascinerende, men samtidig urovækkende. Praktisk talt alle dannede skribenter tog udgangspunkt i en idealistisk dyrkelse af det 'organiske', dvs. forestillingen om helheden som en sammenhængende enhed af forskellige dele, der hver havde sin rette plads, men ikke kunne fungere rigtigt uden den 'organiske' forbindelse til helheden. ${ }^{10}$ Krisen bestod derimod, som J.L. Heiberg formulerede det i 1833, i et forfald i det endelige, adskilt fra det uendelige. ${ }^{11}$ Nogle af de konstituerende elementer i denne krisefornemmelse var den franske revolution som en radikal historisk bruderfaring og indordningen af det danske samfund under det kapitalistiske verdensmarked, først og fremmest reflekteret i omvæltningerne i de danske landbokår, men mere umiddelbart for den skrivende, dannede offentlighed også i den gradvise fremvækst af markedsvilkår i den litterære produktion til afløsning af ældre tiders privilegieordninger. ${ }^{12}$

Monrad synes i sine studieår at have hentet inspiration i det politiseringskritiske miljø omkring Heiberg. Hans tidligste offentliggjorte skrifter fra denne tid var litteraturkritikker, der meget i Heibergs ånd fordrede en filosofisk betragtning af poesiens refleksioner »som concrete Aabenbaringsformer af det Fornuftige «, på enheden af form og indhold og på en sammenhængende verdensanskuelse formidlet gennem digterværket som helhed. ${ }^{13}$ I samme periode, og måske inspireret af Heiberg, knyttede Monrad an til Hegels filosofi som det, der »skænkede den rystede Sjæl Tro ${ }^{14}$

Hegelianismen var ganske vist ikke snævert knyttet til Heiberg, men indgik i en bred kulturhistorisk bevægelse, hvori grundtanker fra Hegel blev udbredt ad mangfoldige veje, ofte i populariserede, forenklede former. I danske kulturkredse voksede den frem i løbet af 1830'erne, især 
som led i diskussioner om nye politiske former, den religiøse legitimerings forfald og de generelle krisefornemmelser. ${ }^{15}$ Navnlig de liberale skribenter så en støtte for deres reformønsker i Hegels fordring om politiske former, der svarede til det aktuelle stadie i fornuftens verdenshistoriske fremvækst, hvilket for det 19. århundrede indebar en universel fordring om forfatninger ud fra den franske revolutions principper om menneskeog borgerret. ${ }^{16}$ Ligeledes lagde mange vægt på Hegels begreber om det borgerlige samfunds individuelle interesser og staten som fællesvæsen, fremstillet som to adskilte, men dog indbyrdes afhængige sfærer ( $H W 7$, p. 339ff, 306; $H W 12$, p. 62). Hegelianismen var således på samme tid en udfordring til gamle legitimeringsformer og baseret i det bestående, en fremtidsorienteret udvej fra den aktuelle kulturkrise hen mod en ny organisk helhed, båret af fornuft frem for tro eller følelse.

Da Frederik den Sjette døde den 3. december 1839, håbede de liberale, at tronfølgeren Christian den Ottende ville realisere deres håb om en forfatningsreform 25 år tidligere havde han godkendt Norges Eidsvollforfatning, der efter datidens forhold var blandt Europas mest liberale. Af stor symbolsk værdi blev konfrontationen mellem liberale forhåbninger og en mere moderat kurs på et studentermøde på hotel d'Angleterre allerede om aftenen den 3. december. D.G. Monrad gjorde her sin debut som liberal offentlig skikkelse, da han tog ordet for at forsvare forfatningssagen og gik med i den reformvenlige af de to delegationer, som mødet sendte til kongen. ${ }^{17}$

Selv om de liberale bestræbelser atter led nederlag, blev de startskud til både Monrads Flypende politiske Blade og en bredere forfatningsdebat, præget af tre hovedstandpunkter. ${ }^{18}$ Det mest markante var den historiefilosofisk begrundede liberale fordring om en fri forfatningsudvikling, som især dagbladet Fedrelandet forsvarede. Det absolutte monarki havde ifølge Fadrelandet nok i sin tid tjent til at styrke statens enhed, men nu var dets rolle udspillet, og en konstitutionel udvikling med større indflydelse til den dannede middelstand måtte til for at knytte Danmark til »det civiliserede Europa $\ll .{ }^{19}$ Monrad delte denne opfattelse og indgik i Fedrelandets redaktion i 1840-41. Det andet standpunkt var et mere konservativt forsvar for enevælden, formuleret af blandt andre den agtede jurist, kancelliråd A.S. Ørsted. Hans hovedargument var, at mens en skreven forfatnings garantier kun var formelt juridiske, så rummede enevælden »moralske Garantier «, der var mere solide, fordi de var forankret $\mathrm{i} »$ organiske Indretninger $\ll$ og $»$ et Folks hele sociale Tilstand $«{ }^{20}$ Et lignende standpunkt blev forfægtet af filosofiprofessor F.C. Sibbern, der også specifikt kritiserede Monrads manifest. ${ }^{21}$ Det tredje standpunkt, som især blev forsvaret af dagbladet Kjøbenhavnsposten, kan betegnes som 
demokratisk eller radikalt. Her vægtede man kritikken af den sociale nød og så »Demokratiet « og en »folkelig « valglov med valgret til »den store umyndiggjorte Mængde« (hvilket nok bør tolkes i retning af: alle voksne mænd) som det bedste middel til at sikre staten mod indre uro. ${ }^{22}$

Som helhed fremviser disse tre standpunkter nogle af de mest grundlæggende indbyrdes spændingsforhold, som kom til at præge de politiske landskaber op gennem det 19. og 20. århundrede, i Danmark såvel som andre steder. Denne akutte skærpelse af politisk-ideologiske modsætningsforhold er samtidig en væsentlig baggrund for forståelsen af afgrænsningsbehov og indre spændinger i Monrads politiske manifest.

\section{Monrads udgangspunkt: Krisediagnose}

Rammen om Monrads tekst er en specifik udlægning af periodens vidt udbredte krise- og overgangsfornemmelse. Den krise, som her omtales, angår den danske enevældige stat og består af tre sammenhængende træk: »Udvortes Afhængighed, Tendents til indvortes Sønderlemmelse og uhyre Svækkelse i finantsiel Henseende « (FpB I, p. 34). Danmark er med andre ord ikke en autonom stat, men lader sin politik afhænge af udenlandske statsoverhoveder; det er splittet i sit indre, bl.a. ved stænderforsamlingernes fastholdelse af provinsskel; og det befinder sig i en finansiel krise, som får staten til at gribe til moralsk fordærvende tiltag som tallotteri. Alle tre elementer i kriseanalysen tager således udgangspunkt i en kontrast mellem et ideal om nationens myndighed og autonomi (»Landets Selvstændighedsfølelse «, FpB I, p. 6.) på den ene side og konstateringen af nationens umyndighed og heteronomi på den anden.

Monrad bruger ganske vist ikke selve ordet 'krise', men derimod en i datiden synonym sygdomsmetafor: »Staten er syg og dens Organisme forstyrret « $\left(F p B\right.$ II , p. 3). ${ }^{23}$ Samtidig bruger han ordet »Gjæring « (FpB II, p. 4.). Sygdoms- eller krisediagnosen forbindes altså med en fornemmelse af uro, dynamisk proces, foruden den opfattelse af historiske overgang fra én tilstand til en anden, som skal berøres senere i forbindelse med hans statsfilosofi. Denne krisebestemmelse minder om Heibergs krisediagnose fra 1833 ved sit progressive perspektiv på krisen og borgernes aktuelle 'lave' standpunkt som en mellemvej fra det overleverede til en ny, filosofisk ophævet 'højere form' for politik. ${ }^{24}$ Mens Heibergs højere form imidlertid er pointeret 'ideal' i modsætning til den aktuelle 'reale', dvs. atomiserende, politisering, så ser Monrad mere optimistisk politiseringen som et højere ideal og en udvej fra det 'lave' standpunkt. ${ }^{25} \mathrm{Og}$ mens Heiberg ser politiske partikampe som trusler mod det autentiske individ, ser Monrad dem som nødvendige midler til den højere form. ${ }^{26}$ Hans samlede 
bud på en kriseløsning er dermed også politisk: »det nye Princip, som staaer i Begreb med at udfolde sig i Statsstyrelsen « (FpB I, p. 4) - dvs. den historisk nødvendige indførelse af konstitutionelt monarki.

I tanken om historisk nødvendighed ligger her ikke kun en teoretisk baseret prognose om uundgåelighed i den objektive udvikling, men også et opråb til handling, et praksisbetinget imperativ: En konstitution vil være nødvendig, hvis den allerede igangværende udvikling skal leve op til sit 'begreb'. ${ }^{27}$ Opfattelsen af, hvordan sagerne bør stå, og hvilken retning udviklingen bør tage, udtrykkes således ved et på én gang deskriptivt og performativt udsagn om, hvordan situationen $e r$, og hvilken retning udviklingen går. ${ }^{28}$ Som i det ligeledes hegeliansk funderede kommunistiske manifest kædes argumentationen sammen dels af enheden mellem subjekt og objekt, karakteriseret ved objektets subjekt-konstruerede og dermed foranderlige karakter, dels af en grundopfattelse af væren som vorden, dvs. en grundlæggende opfattelse af verden som udvikling snarere end tilstand (Jf. $H W 5$, p. 83ff, samt f.eks. $H W 3$, p. 23). Denne tilgang gør det oplagt at søge grundlaget for fremtidsprognosen i tendenser inden for det allerede eksisterende. Hvor Marx og Engels performativt prognosticerer proletariatets revolution ud fra en analyse af det borgerlige samfunds verdenshistoriske krise, prognosticerer Monrad tilsvarende performativt en konstitutionsreform rodfæstet i en analyse af den enevældige stats verdens- og nationalhistoriske krise.

Det er således en hovedpræmis for Monrads argumentation, at Danmark allerede er, hvad det vil blive, og at det kun kan bevares som det, det er, ved at ophæve sig til noget andet. ${ }^{29}$ Af samme grund kan forslaget om enevældens afskaffelse hævdes ikke at bero på fortidsdyrkelse, fremtidsspekulationer eller kritik af regeringen, men blot være en beskeden undersåts betragtninger over den aktuelle situation. ${ }^{30}$

\section{Staten som bistorisk dannet fornuft}

Denne grundtanke udfoldes her historiefilosofisk i en fremstilling af det konstitutionelle monarki som en syntese af frihed og statslig enhed, frembragt historisk gennem kampe og modsætninger - »den for hele Verdensudviklingen gjældende dialectiske Bevægelse " (FpB III, p. 14). Friheden er ifølge Monrad »Europas Grundtanke«, og dens udvikling skildres gennem tre stadier. Selv om dette således er generelt for den europæiske civilisation, er det sigende, at han, som det vil fremgå nedenfor, undervejs næsten umærkeligt - og måske endda ubevidst - indsnævrer rammen til »Landet", dvs. det enkelte lands udvikling. Udviklingsmodellen gælder således både civilisationen og det enkelte land som et led heri. 
Friheden fremtrådte ifølge Monrad først ensidigt som »Stænders (Adels og Geistligheds), Stæders og Provindsers Privilegier, hvorved Landets Dele splittedes, dets Kræfter lammedes, dets Enhed opløstes«. I modsætning til denne frihed uden enhed måtte der opstå »en ligesaa eensidig Eenhed, der nivellerede Alt under sin souveraine Enevælde« (FpB I, p. 19. Jf. $H W 12$, p. $32 \mathrm{og}$ passim). I denne sikring af enheden og af lovens herredømme ligger »det absolutte Monarchies historiske Nødvendighed « og grundlaget for, at denne statsform gradvis afsondrede sig fra despotismen, dvs. den blot vilkårlige magtudøvelse. ${ }^{31}$ Igen kan 'historisk nødvendighed' tolkes både som objektiv uundgåelighed og praktisk nødvendighed med henblik på den senere udvikling.

Over for både den ensidige frihed og mangfoldighed uden enhed og den ensidige enhed uden frihed og mangfoldighed fremstilles det konstitutionelle monarki som en syntese - »Samklang « - af friheden og enheden som de to grundelementer i staten ( $F p B$ I, p. 19f.). Dermed opnås en ny organisk tilstand, »en organisk Samvirken « af de forskellige momenter i staten ( FpB I, p. 24, jf. p. 19). Og dermed realiseres friheden i den eneste form, hvorunder den kan eksistere vedvarende, nemlig under loven. ${ }^{32}$

Denne udviklingsproces er således identisk med statens og lovens fremvækst. Staten er ifølge Monrad »grundvæsentlig for den menneskelige Natur, thi den er bygget paa Tanken, og Tanken omfatter det Enkelte og forener det i det Almindelige « (FpB I, p. 19. Jf. f.eks. HW 12, p. 56f, 66). Den er med andre ord en historisk fremvokset fornuft. Kravet om en friere forfatning betyder dermed heller ikke en svækkelse, men en styrkelse af staten gennem enheden med folket: »Folkets Villie skal som en levendegjørende Aand gjennemtrænge Regjeringen og gjennem den udfolde sin Magt paa hele Statens Organisme. «33 Idet lovens væsen er identisk med statens, altså »det Almindelige, som omfatter og underordner sig det Enkelte«, kommer den almene lovs fremvækst under det absolutte monarki i strid med den absolutte monarks menneskelige individualitet, der rummer en rest af vilkårlighed (FpB I, p. 19, 10, 13, 20; II, p. 9). Loven står således for Monrad ikke blot over vilkårligheder i folkets udvikling, men også over monarken som individ.

Af samme grund vil konstitutionen kunne indføres lovligt og ikkerevolutionært ved at lade »Kongehaand sætte Seierskrandsen paa Folkets Isse « (FpB I, p. 35 ). ${ }^{34}$ Monrad beundrer ganske vist de franske revolutioner i 1789 og 1830 som hævdelse af henholdsvis menneskerettighederne og borgerrettighederne. ${ }^{35}$ Han skelner imidlertid grundlæggende mellem den store franske revolutions forbigående former og dens varige indflydelse på civilisationen. Mens han håber, at denne indflydelse vil »afspeiles« i Danmark, ønsker han ikke at overføre de revolutionære former 
til sit hjemland. ${ }^{36}$ Sådanne forceringer af friheden vil nemlig føre til en bestandig, resultatløs vekslen mellem revolutionære og reaktionære perioder, som vil »bevirke, at Folkeudviklingen kommer til at ligne Pendulets Svingninger $\ll{ }^{37}$

Dette er en hegeliansk historiefilosofisk fremstilling, både ved at skildre frihedens fremvækst gennem dialektiske negationer og ved at se fornuftens gradvise emancipation i sin historiske hovedform: staten (Jf. $H W 12 ; H W$ 7, pp. 508-11). ${ }^{38}$ Frihedens historiske syntetisering med enheden er den moderne stats fremvækst som fornuftens virkeliggørelse. Den nøjagtige sammenfatning af forløbet ensidig fribed - ensidig enhed - syntese af fribed og enhed er dog ikke absolut specifik for Hegel, men præger også andre af periodens udbredte universalhistoriske tolkninger, der i praksis ofte blev læst i sammenhæng med Hegel, herunder François Guizots forelæsninger fra 1828 om den europæiske civilisation. ${ }^{39}$

Monrads historiefilosofisk forankrede analyse af enevældens forbigående historiske nødvendighed danner samtidig udgangspunkt for hans strukturelle afgrænsning fra politiske alternativer. På den ene side afgrænser han sig fra radikal forandringstrang, revolutionære forandringsformer og »over-reformatoriske« bestræbelser, der ifølge ham ofte hviler på »den mindre Oplyste[s] « forveksling af det absolutte monarki med despoti ( $F p B$ III, p. 16, FpB I, p. 9f.)..$^{40}$ På den anden side afviser han også "conservative« og »overreactionære « bestræbelser på at fastholde overleverede former og dyrke orden og enhed på frihedens bekostning. De konservative sammenblander ifølge ham »Død med Orden, fordi det Døde jo ogsaa er meget ordentligt og roligt, og Liv med Anarchie, fordi der i det Levende er Bevægelse«(FpB I, p. 11, 18; FpB III, p. 15f.).

\section{Folk, bevidsthed og civilisation}

Det begreb om folket eller nationen, ${ }^{41}$ som udvikles i sammenhæng med statsbegrebet i denne tekst, er ikke alene emne og adressat for fremstillingen, men også et talersubjekt: »vi Danske « (FpB I, p. 23). Begrebet har her en mængde betydningsaspekter og sammensætninger: folkeånd, folkebevidsthed og folkeliv. Det forekommer oftest sammen med ord som 'frihed', 'kraft', 'følelse' eller 'genvækkelse'. Hvor 'liv' og 'ånd' således signalerer sammenhængende organicistiske og idealistiske positive værdier, er modbegreberne åndløshed, rå lidenskab, død eller 'slummer'. Den flittigst brugte folke-sammensæetning i Flyvende politiske Blades første nummer er således 'folkeliv', der skildres som en organisk enhed i modsætning til »de døde Masser «, dvs. det passive og atomiserede fællesskab ( $F p B$ I, p. 22, 23, 30, 35; FpB I, p. 35 ('døde masser')). ${ }^{42}$ 'Folkeånd' og 'folkeliv' 
er derudover tæet forbundne med de delvis overlappende betydninger af ordene 'offentlig mening' og 'almenånd', der dels betegner borgernes deltagelse i det politiske fællesskab i modsætning til deres mangfoldige særinteresser, dels både sprogligt og praktisk indebærer et ideal om åbenhed, herunder krav om friere forhold for diskussion af offentlige forhold ( FpB I, p. 24, 15; FpB III, p. 14). ${ }^{43}$ Da en række af disse betydningsforbindelser nødvendigvis rækker ud over deres betydning alene for det enkelte 'folk', virker folkebegrebet tillige, som det vil fremgå senere, sammen med både mere almene begreber som 'civilisation' eller 'menneske' og mere partikulære begreber som 'individ' eller 'provins'.

Hele dette felt af mere eller mindre ækvivalente eller overlappende begreber, 'folk', 'folkeliv', 'folkeånd', 'almenånd', 'offentlig mening' osv. skal forstås organisk-holistisk, dvs. som helheder, der er mere og andet end summen af deres enkeltdele. I denne begrebsbrug ligger en kritik af social atomisering som det, Hegel kaldte 'slet uendelighed', dvs. en uendelig ophobning af enkeltheder eller individer uden indre sammenhæn $(H W 7$, p. 342f $(\$ 185)$. Dette træk kan også forklare høje Monrads kvalitative krav til afgrænsningen af folket, herunder hans udsondring af en 'kerne' i folket, som tilkendes særlige forudsætninger for at kunne erkende og formulere folkets udsyn, dvs. den offentlige mening.

Monrads brug af begrebet 'folk' lægger sig overordnet på linje med sin tids liberale brug og i forlængelse af den dobbelte relationelle betydning af det, som især blev udbredt på europæisk plan med den franske revolution i 1789: en vertikal skelnen mellem 'folket' og staten eller de herskende eller privilegerede, og en horisontal skelnen mellem det ene folk og det andet. ${ }^{44}$ Således taler Monrad både om forholdet mellem 'folket' og regeringen' og om forholdet mellem det danske folk, det tyske og de øvrige skandinaviske folk. ${ }^{45}$

Går man tæuttere på hans brug af folkebegrebet, finder man også aspekter, som er mere særegne for ham selv og den politiske bevægelse, han taler for. Selv om han betragter de moderne europæiske stater som produkter af en historisk udviklingsproces, så røber nogle af hans formuleringer om 'folket' en tilbøjelighed til at sætte denne størrelse forud for sådanne historiske udviklinger. Mens staten er »Aandens Produkt«, er »Nationalitetens Bevægelser (...) en Naturmagt «, skriver han få år senere. ${ }^{46} \mathrm{I}$ hans ovenfor citerede erklæring, at Christian den Ottende vil gøre folket til borgere, er det således påfaldende, at folket antages at have været et folk, endnu inden Frederik den Sjette gjorde det til mennesker. Og frem for at beskrive f.eks. folkets fremvækst eller dets modning taler Monrad konsekvent om dets 'genvækkelse' fra en lang 'slummer'. Implikationen er ikke blot, at folket har eksisteret hele tiden, men også at det før har vist 
sig mere vågent end nu.

Tilsvarende synes Monrad at iblande sin fremstilling af statens dialektiske fremskridt en forestilling om oprindelig folkefrihed: »[D]en absolute Eenhed $[\ldots]$ gjenføder $[\ldots]$ i en forædlet Form den Frihed, som vi have eiet i de gamle Dage« (FpB I, p. 20). Da Monrads ærinde næppe er at forsvare de »Stænders (Adels og Gejstligheds), Stæders og Provindsers Privilegier ", som i hans hegeliansk inspirerede fremstilling var resultatet af frihedens første historiske fremtræden, må det »vi«, der her hævdes at have genvundet den gamle frihed, tolkes som folket - 'vi danske'. Hermed indarbejder Monrad ikke-hegelianske opfattelser af en oprindelige nordisk folke- eller bondefrihed, som bl.a. har rødder i 1700-tallets diskussioner om landboreformer, men som også ses hos Monrads samtidige liberale tankefæller, bl.a. Orla Lehmann og historikeren C.F. Allen - og som en almen historiefilosofisk forestilling om genvinding af den tabte oprindelighed i Henrich Steffens' filosofiske forelæsninger fra 1802. ${ }^{47}$

Alligevel vægter Monrad det nye og det moderne højest, især ved at understrege fornuften og samvirket mellem de europxiske folk. Ganske vist taler han stedvis om nødvendigheden af en folkefølelse ( $F p B$ I, p. 18). Denne følelse knyttes imidlertid til en formuft og en erkendelse, der er moderne produkter, forbundet med europæiske bevægelser. Gennem en fri presse, der kan formidle kendskabet til fremmede nationers »Grundvæsen og Grundtanker «, skriver han, kan også det danske folk vågne »til Selvbevidsthed « (FpB I, p. 14).$^{48}$ Denne selvbevidsthed står ikke i modsætning til folkets lydighed over for monarken, men den moderne lydighed må være en »seende Lydighed «, ikke en blind ( FpB I, p. 15). Den moderne lydighed bygger med andre ord på den historisk fremvoksne fornuft eller anden hos borgerne, der selv erkender behovet for at adlyde staten for at fremme den organiske enhed. ${ }^{49}$ Hermed forbindes begreberne 'folkeånd' og 'folkeliv' med begreberne 'fornuft', 'dannelse' og 'kultur' - en væsentlig forudsætning for den normative afgrænsning af 'folkets kerne', som skal omtales lidt senere.

Tilsvarende polemiserer han mod dels 'nationalstoltheden', dvs. viljen til at underkaste andre nationer sin egen nations herredømme, som i Napoleons imperiale ekspansionstrang, dels 'nationalforfængeligheden', dvs. den opfattelse af nationale selvtilstrækkelighed, der ofte blev brugt i konservative argumentationer for at stemple enhver konstitutionalisme som fremmed for det danske folk i kraft af dens udenlandske rødder. Denne 'nationalforfængelighed' mødte de liberale på den tid i mest udfoldet form hos F.C. Sibbern og i den opfattelse af 'folk', 'folkeliv' og 'folkeånd', der gjorde sig gældende i miljøet omkring N.F.S. Grundtvig, ikke mindst hos Jacob Christian Lindberg. ${ }^{50}$ Lignende argumenter 
udvikledes, om end mere udpræget tvetydigt, i den politiseringskritiske skribentkreds omkring Heiberg, blandt andre Henrik Hertz, Peder Hjort og Søren Kierkegaard. ${ }^{51}$

Herimod sætter Monrad 'nationalfølelsen', der forbindes med kravet om statens selvstændighed i sameksistens med andre stater og dens styrke gennem folkets engagement i statslivet (FpB I, p. 23, 29) ${ }^{52}$ Det danske folks nationale selverkendelse hævdes hermed at opnås gennem kontakten til andre europæiske folk, som er foran det danske i udviklingen, men også ved sammenligning af kontraster, f.eks. mellem det franske folks revolutionstilbøjeligheder og det danske folks roligere karakter. Så selv om Monrad tilskriver nationen eller folket oprindelighed, står civilisation og menneskehed som forudsætninger for folkelivets genvækkelse, og en væsentligst forudsætning for det danske folks 'genvækkelse' er en moderne tvær-europæisk fordring om forfatningsrettigheder.

Monrads forankrer dog samtidig karakteristisk det kommende i det bestående ved at understrege, at enhver forfatningsudvikling må være 'national' i den forstand, at den må respektere »Folkets Individualitet" og tage udgangspunkt i de »stedfindende Forhold « i det givne land ( FpB I, p. 4, 2). ${ }^{53}$ Ligeledes er et hovedelement i hans tekst kritikken af den tyske indflydelse på danske forhold. Dette giver hans argumentation en fundamental præmis til fælles med den 'nationalforfængelighed', som han kritiserer. Hans senere involvering i stridighederne med Tyskland styrkede hans vægtning af de horisontale modsætninger mellem folkeslag. Derved nærmede han sig gradvis det 'nationalforfængelige' standpunkt og gav større vægt til de konservative aspekter af hans insisteren på en udvikling i kontinuitet med det bestående i en snævrere national forstand. ${ }^{54}$

I manifestet fra 1839 tilkendes 'folkelivet' og 'folkets individualitet' dog endnu bemærkelsesværdigt åbne grænser, både indadtil og udadtil: Indbyggernes individualitet og deres provinsforskellighed inden for det enkelte land kan således anerkendes som positivt, for så vidt som de organisk indordnes under folket som helhed og dermed ikke dyrkes ensidigt: » $[\mathrm{M}]$ ed det vakte og frigjorte Folkeliv vækkes og frigjøres ogsaa den provindsielle Forskjellighed, og med det splittede Folkeliv gjøres Forskjelligheden selvstændig. «( $F p B \mathrm{I}$, p. 22). Ligeledes forstås det enkelte folks liv og individualitet i en bredere europæisk kulturel eller civilisatorisk enhed. ${ }^{55}$ Fordringen om en genvækket folkeånd forbindes med en stærkere tilknytning til det progressive Vesteuropa, hvis frihed står i modsætning til det østens despoti, som Danmark ifølge Monrad har nærmet sig med sine kun rådgivende provinsialstænder og sin censurlovgivning ( $F p B$ II, p. 17). ${ }^{56}$ Tilsvarende understreges sammenhængen mellem det danske folks nationale selvstændighed, forfatningsbestræbelserne og enheden mellem 
de skandinaviske folk (FpB I, p. 29; II, pp. 18-22). ${ }^{57}$ Dette indvarsler 1840 'ernes skandinavisme, som afgørende prægede senere idealer om nordisk enhed..$^{58}$

Det betydningsaspekt af begrebet 'folkeliv', der lægger sig til 'offentlig mening' og dermed til et ideal om åbenhed, kommer hos Monrad til udtryk i en støtte til den moderne politiske presse og en kritik af censuren. Her indgår hans betragtninger i en bredere debatkontekst. En del af politiseringskritikken hos Heiberg, Kierkegaard, Hertz og andre var en beklagelse over den moderne journalpresses binding til partiinteresser og dens tvangsdyrkelse af nyheden på bekostning af eftertænksomheden og helhedsforståelsens bekostning. ${ }^{59}$ Monrad beskriver herimod den politisk liberale presse som et væsentligt led i folkets opvågnen til selvbevidsthed og kræver elementerne af censur afskaffet ( FpB I, p. 14).${ }^{60}$ Mens trykkefriheden, som andre friheder, for Monrad nødvendigvis må indebære et ansvar for loven, så er censuren et despotisk levn, en »Ulov«. Den strider nemlig mod selve lovens begreb - dvs. det, der må være alment - ved at bringe monarken som udøvende magt i »en umiddelbar Berøring med den enkelte Tilfælde« (FpB I, p. 16, 13).

\section{Folkets kerne og den offentlige mening}

Monrads krav om politisk anerkendelse af folket fører ham til at afvise politiske repræsentationsformer, som er for 'aristokratiske', enten ved at give for stor magt til godsejerne eller til »enkelte Rigmænd« (FpB III, p. 6). I denne negative positionering ligger fællestræk med en demokratisk diskurs. Både Monrad selv og den liberale bevæegelse som helhed anerkendte da også, sandsynligvis efter inspiration fra Alexis de Tocqueville, at demokratiet, forstået som lighed mellem menneskene og navnlig 'middelstandens' fremvækst, og dets sejr over aristokratiet, dvs. uligheden, var en uafvendelig tendens i tiden. ${ }^{61}$

I samme åndedrag afviste Monrad dog en for 'demokratisk' valglov (FpB III, p. 6). De liberale i miljøet omkring ham understregede, at demokratiske lighedsbestræbelser ofte var knyttet til despotiske overgreb på friheden, ikke mindst i den franske revolution. Ligesom Tocqueville ville de af det fremvoksende 'demokrati' udvikle »Institutioner, der svare til de tidligere aristocratiske, men fremtræde i en friere, æxllere, til Tiden svarende Form «.62

Den nye form for friere og mere demokratiseret 'aristokratisk' berettigelse, som derimod anerkendes hos Monrad og hans meningsfæller, peger mod dannelse og besiddelse som forudsætning for politisk deltagelse. Dermed ekskluderes selvsagt de 'udannede'. Den fordring om almindelig 
stemmeret, der i samtidens forfatningsdebat som nævnt blev anbefalet af Kjøbenhavnsposten, vil ifølge Monrad betyde en overdragelse af magten til »den raa uoplyste Masse, hvis Liv udelukkende er offret en Kamp for Livets første Fornødenheder, og hvis Aand ei faaer Hvile til at beskjæftige sig med Fædrelandets Anliggender « (FpB III, p. 7). ${ }^{63}$

Den offentlige mening kan derfor ifølge Monrad ikke formuleres af folket som helhed, men kun af »Middelstanden «, dvs. embedsstanden og de dannede og besiddende borgere. ${ }^{64}$ Denne middelstand udgør i kraft af sin intellektuelle dannelse og sociale selvstændighed en »Folkets Kjerne «, der omfatter »ihændehaverne af Folke=Oplysningen og Landets materielle Styrke « og derfor kan udtrykke »Massernes Sjæl «, »Folkets Fælleds=Tanke $«\left(F p B\right.$ III, p. 6, 5, 13). ${ }^{65}$ Det skyldes især, at middelstanden i kraft af sin sociale stilling og dannelse kan hæve sig over partikulære interesser og varetage folkets og statens interesser som helhed. Derfor bør middelstanden også gives forret i valgloven ( FpB III, pp. 5-7). De endnu udannede vil nok med tiden kunne træde ind i borgernes rækker, men kun hvis de bliver dannede og dermed træder ind i den eksisterende 'middelstands' rækker. ${ }^{66}$ At der i løbet af 1840'erne kom visse taktisk betingede indrømmelser i demokratisk retning fra de nationalliberale, vigtigst i forhold til bønderne og i 1848 også de lavere sociale lag i byerne, xndrede ikke på de liberales grundforagt for de 'udannede' ${ }^{67} \mathrm{De}$ politiske implikationer af begrebet 'folk' afgrænses dermed vertikalt ikke blot 'opad', dvs. over for den herskende elite, men også 'nedad', dvs. over for de udannede og dermed politisk uberettigede dele af dette folk. Der er derfor intet underligt i, at Monrad i samtiden blev kritiseret for at være ufolkelig. ${ }^{68}$

En væsentlig teoretisk forudsætning for Monrads afgrænsning af den offentlige mening til 'folkets kerne' er, at denne ikke forstås som en empirisk-kvantitativ sum af meninger, men tværtimod som én organisk sammenhængende mening - meget lig Rousseaus skelnen mellem 'almenviljen' som det udelelige udtryk for en stats fælles interesser og 'alles vilje' som en tilfældig ophobning af enkelte bestræbelser. ${ }^{69}$ Mere specifikt bestemmes 'folkets kerne' og dens politiske berettigelse hos Monrad kvalitativt, dels af de politiske debattørers socio-økonomiske klassetilhørsforhold, dels af indholdet i det politiske udsyn. Dette udsyn kan nok rumme visse indre modsætninger og spændinger - Monrad anerkender som nævnt politiske stridigheder og differentiering som nødvendige forudsætninger for en virkelig syntese. Disse stridigheder kan dog kun berettiges inden for en fælles anerkendelse af staten som overordnet og de bredere folkemasser som underordnede.

I den danske debatkontekst omkring 1840 placerer hans brug af be- 
grebet 'folkets kerne' sig pragmatisk mellem bestemmelser af henholdsvis denne kerne som middelstanden i modsæxtning til embedsstanden og som embedsstanden først og fremmest. ${ }^{70}$ Med alliancen mellem bønder og liberale borgere i 1840'erne blev gradvis også bønderne, dvs. gårdmændene, udpeget som 'folkets kerne', fordi de var de oprindelige borgere og besad den økonomiske selvstændighed, der gav mulighed for åndelig dannelse. ${ }^{71}$

Monrads forestilling om statens rekonstruktion ud fra en organisk borgerlig offentlighed bestående af en lille gruppe formelt ligestillede borgere adskiller sig fra Hegels fordring om en stænderrepræsentation, der kan anerkende en betydeligt større gruppe som borgere ved f.eks. også at omfatte forskelle i socio-økonomisk stilling. ${ }^{72}$ Den kan imidlertid betragtes som hegeliansk i bredere forstand. Den ligger da også ret tæt på den politiske filosofi hos hegelianismens måske vigtigste tyske fortaler i 1820 'erne og 1830'erne, Eduard Gans. ${ }^{73}$ Andre i samtiden foretrak derimod at finde et konstitutionelt kompromis mellem 'demokrati' og 'aristokrati' ved at afbalancere de forskellige sociale interesser, f.eks. gennem et tokammersystem. ${ }^{74}$ Derved relativeredes i det mindste begrebet om 'folkets kerne'.

Monrads identifikation af den offentlige mening med de liberale dannede mødte kritik fra især F.C. Sibbern, der i konstitutionsfordringen så truslen om en bestemt klasses eller et bestemt partis diktatur - indførelse af en fri forfatning ville ifølge ham være ensbetydende med at »skifte Herre«. Ved at understrege det organiske helhedsideals differentieringsgrundlag og dermed indlemme et større udsnit af befolkningen i den offentlige mening kunne han hævde, at »den fremherskende Stemning i Danmark " på ingen måde stemte overens med Monrads liberale »Hegelianisterie ${ }^{75}$ I denne kritik forenes et forsvar af enevælden som tradition med spirer til en social kritik af den moderne kapitalisme. ${ }^{76}$ Samtidig antyder dette en tendens i perioden til spaltning af 'offentligheden' i flere indbyrdes stridende offentligheder. ${ }^{77}$ Når Monrad taler om 'den offentlige mening', er det med andre ord mere performativt end konstaterende.

Monrads og den liberale bevægelses udsyn er dermed hverken demokratisk ud fra senere fremherskende demokratiforståelser eller ud fra periodens egne begreber. Nok findes her elementer af demokratisk retorik, men kravet om udbredelse af den politiske magt går kun netop så langt som det er nødvendigt for at sikre det dannede og besiddende borgerskabs politiske herredømme. 


\section{Konklusion: Manifestets ideologiske funktion}

Monrads manifest fra 1839, efter små ti års politisering af den danske offentlighed, bidrog således ikke kun til at definere og forene den liberale bevægelse op til 1848. Det formulerede også en særlig social strategi $\mathrm{i}$ overgangen til en moderne stat og et borgersamfund med rødder i en generaliseret vareproduktion. På grundlag af en hegeliansk historiefilosofisk forankring af grundbegreberne 'stat' og 'folk' afgrænser denne strategi sig mod to sider: dels det konservative forsvar af det bestående, dels de radikale eller demokratiske enevælde-kritikker, der tillige omfatter ulighedens sociale og økonomiske aspekter. Monrads argumentatoriske hovedstrategi er her at fremstille det bestående som led i en gradvis udvikling, der med historisk nødvendighed, herunder den praktiske nødvendigheden af politisk intervention, må føre hen mod det konstitutionelle monarki. Denne statsform står dermed som fuldendelsen af det moderne borgersamfund, der selv betragtes som kulminationen på en langsigtet verdenshistorisk dannelsesproces.

Dette giver Monrads liberale manifest karakter af en oppositionel, fremtidsrettet udfordring i den øjeblikkelige situation, men samtidig en begrænsning af det verdenshistoriske perspektiv til realiseringen af de almene rammer for dette borgerlige samfund, styret efter det dannede og besiddende borgerskabs retningslinjer. Når dette er opnået, kan den verdenshistoriske proces ud fra Monrads hegelianske tankemåde betragtes som afsluttes i sine væsentligste berettigede aspekter. Hans standpunkt rummer for så vidt et antipolitisk element, der ligner Heiberg-miljøets, så snart det drejer dig om den politiske deltagelses demokratisering til de lavere sociale lag. Al videre progressiv bevægelse tænkes kun som en kvantitativ udvidelse af det dannede og besiddende borgerskabs andel af samfundshelheden.

Tilsvarende rummer den dobbelttydige bestemmelse af den danske nations forhold til den bredere civilisations udvikling flere udviklingsmuligheder, dels for progressive åbninger for menneske- og borgerretsfordringer på tværs af landegrænser, dels for en mere 'nationalforfængelig' modstilling af folkeslag. I Monrads manifest afvises det sidste alternativ endnu, men efterhånden kom det til at dominere det nationalliberale borgerskabs politiske praksis.

Det dannede og besiddende borgerskab substituerer således for 'folket'. Ligeledes substituerer grundbegreberne 'dannelse' og 'stat' i vidt omfang for en markedsdiskurs. Dette er et udbredt træk ved datidens liberalisme, navnlig dens kontinentaleuropæiske udgaver. Frem for at in- 
debære en afstandtagen til udviklingen af en markedsøkonomi kan denne substitution betragtes som et forsøg på at imødekomme udfordringerne fra de i vidt omfang statsformidlede tilpasninger til det internationale marked, som gjorde sig gældende på kontinentet, og navnlig i småstater som Danmark, ved at opbygge moderne stater med forbedrede funktionelle forudsætninger for de nationale kapitalers understøttelse.

De signifikante begrænsninger for det demokratiske og verdensborgerlige indhold i Monrads udsyn forhindrede dog ikke, at det kritiske potentiale i en række af hans tanker kunne videreudvikles i mere radikal og demokratisk retning. Dette var dog op til andre bevægelser og samfundsklasser. Så selv om Monrad og den moderat liberale bevægelse omkring 1840 lagde grunden til meget i danske politiske traditioner, går der ingen lige linje fra denne tids liberale til nutidige demokratiske tanker.

\section{Noter}

1 Ditlev Gothard Monrad: Flyvende politiske Blade, nr. I, p. 35, København 1839 (herefter $F p B+$ nr.). Denne artikel indgår i forskningsprojektet Politik, antipolitik og historie $i$ dannelsen af moderne politiske kulturer, som er finansieret af Forskningsrådet for Kultur og Kommunikation.

2 Et anonymt skrift fra 1861 citeret i P. Lauritsen: D.G. Monrad. Grundlovens Skaber og Folkefribedens Bannerfører I, København 1950 p. 139. Jf. tilsvarende i C. Hostrup: Erindringer fra min barndom og Ungdom, p. 90; Anthon Frederik Tschernings efterladte Papirer, 3 bd., København, bd. 2, p. 225. Til Monrads levned og tanker i øvrigt: P. Stavnstrup: D.G. Monrad. Politiker og Gejstlig, København 1948; Povl Bagge: Studier over D.G. Monrads Statstanker, København 1936; Asger Nyholm: Religion og Politik. En Monrad Studie, København 1947; Svend Hauge: Studier over D.G. Monrad som religiøs Personlighed, København 1944; Leo Tandrup: »D.G. Monrads syn på konstitutionalisme og parlamentarisme ", in Historie Jyske Samlinger, ny række VIII, 1, 1968, pp. 14-97.

3 Sympatiserende anmeldelser og diskussioner, der vidner om Flyvende politiske Blades betydning for den liberale bevægelse, findes i Fadrelandet 5/11840, 18/6-1840, 24/7-1842, 9/8-1842, 31/8-1842; Den Frisindede 6:25 (29/2-1840), p. 98f; Sjellandsposten, II:17, 29/2-1840, p. 65f. Omvendt blev de kritiseret af absolutismens ihærdigste offentlige forsvarer, F.C. Sibbern, i »Angaaende Magister Monrads flyvende politiske Blade Nr. I og II «, in Søndagen. Et Følgeblad til Dagen, nr. 9, 1/3-1840, og Dagen 19/3-1840; jf. Monrads svar herpå i Fedrelandet 13/3-1840 og 1/4-1840; samt af den tysksindede liberale Theodor Olshausen i dennes Correspondenz-Blatt nr. 46, 20/5-1840, p. 183f. Til dommen over Monrad: Harald Jørgensen: Trykkefribedsspørgsmaalet i Danmark 1799-1848, København 1944, p. 367.

4 Jf. Frank Jørgensen: »Københavnske foreninger 1820 til 1848 «, Historiske Meddelelser om København, rk. 4, bd. 5, 1957, pp. 25-112; Niels Clemmensen: Associationer og foreningsdannelser i Danmark 1780-1880. Periodisering og forskningsoversigt, Øvre Ervik 1987; samt om Monrads arbejde for et nyt 
studentersamfund i 1840 Nyholm Religion, p. $50 \mathrm{f}$.

5 Jf. de forskellige accentueringer af dette som en fastlæggelse af det moderne manifest som genre i Marshall Berman, All That Is Solid Melts Into Air: The Experience of Modernity, London 1983, pp. 87-129; Peter Osborne: »Remember the Future? The Communist Manifesto as Historical and Cultural Form «, in The Socialist Register 1998, pp. 190-204; Martin Puchner, Poetry of the Revolution: Marx, Manifestos, and the Avant-Gardes, Princeton 2006. Ligesom andre glimrende nyere undersøgelser af manifestet som form og genre (bl. a. Marjorie Perloff: The Futurist Moment: Avant-Garde, Avant Guerre, and the Language of Rupture, Chicago 1986, pp. 80-115) har disse analyser dog en tendens til at undersøge dette retrospektivt med udgangspunkt i senere æstetisk-politiske manifester, hvorved Marx' og Engels' manifest fremstilles alene som grundlæggelsesmoment og ikke som produkt af bredere sociale og kulturelle brydninger i Europas revolutionære udvikling 1789-1848.

6 Jf. f.eks. den generelle orientering i Roar Skovmand: Danmarks historie. Bind 11: Folkestyrets fødsel 1830-1870, København 1964; Hans Jensen: De danske Stenderforsamlingers Historie 1830-1848, 2 bd., København 1931-34; samt mere specifikt Jensen Stenderforsamlingers, bd. 2, p. 229f; Steen Bo Frandsen: Opdagelsen af Jylland. Den regionale dimension i danmarkshistorien 1814-64, Århus 1996, pp. 221-26, der ganske vist mere vægter den nationalt centralistiske linje i $F p B$ end det parlamentariske demokratis fremvækst, men dog ser Monrads tekst som en optakt. Selv om Bagge Monrad og Claus Friisberg: Ideen om et frit Danmark, Varde 2003, her især p. 320f; samme: Den danske vej fra enevelde til demokrati. Borger og bonde i overgangsairene 1830 til 1848, Varde 1998, p. 85f; og samme: »D.G. Monrads konservatisme - myte eller realitet? «, in Historie, nr. 2, 1995, pp. 216-32, er mere nuancerede end de øvrige, er hovedinteressen også her den traditionelle politik-historiske. Jon Stewart: A History of Hegelianism in Golden Age Denmark, 2 bd., København 2007, bd. 2, pp. 359-66 søger derimod snævrere efter spor af tekstlig Hegelinpiration i $F p B$.

7 Jf. Jensen Standerforsamlingers; Marcus Rubin: Frederik VI's Tid. Fra Kielerfreden til Kongens Død, København 1895; Friisberg Ideen.

8 Jf. hertil Jensen Stenderforsamlingers, Rubin Frederik; Jørgensen Trykkefrihedsspørgsmaalet; Søren Juelstorp: »Den københavnske intelligens og ytringsfriheden i midten af 1830erne", in Historisk Tidsskrift, rk. 16, bd. 2, 1993, pp. 340-368.

9 Dette overses i traditionelle karakteristikker af disse kredse som konservative, f.eks. Skovmand Folkestyrets, p. 210; Friisberg Ideen, p. 184.

10 Jf. Aage Henriksen m.fl.: Ideologihistorie I: Organismetenkningen i dansk litteratur 1770-1870, København 1975.

11 J.L. Heiberg: Om Philosophiens Betydning for den nuverende Tid, København 1833, p. 9 og passim.

12 Jf. Vagn Wåhlin: »Om tiden 1700-1870 «, in Dansk Socialhistorie: fra Istid til Nutid, Den jyske Historiker, nr. 23-24, 1982, pp. 100-112.

13 D.G. Monrad: »Om Dandserinden, betragtet som reflecterende Poesie«, in Kjøbenhavns flyvende Post 1834, nr. 2. Jf. samme: »Agnete og Havmanden «, in Maanedsskrift for Litteratur, bd. 12, 1834, pp. 109-17. Om den heibergske skole: Paul V. Rubow: Dansk litterer Kritik i det nittende Aarhundrede indtil 1870, København 1921; Finn Hauberg Mortensen: Litteraturfunktion 
og symbolnorm 1800-1870, København 1973, bd. 2; Morten Borup: Johan Ludvig Heiberg, 3 bd., København 1947-49.

14 Monrads eksamenspetitum fra forsommeren 1836, her citeret fra Nyholm Religion, p. 24f. Originalens latinske tekst findes i Hauge Studier, p. 278f.

15 Stewart A History, samt C.H. Koch: Den danske filosofis historie: Den danske idealisme 1800-1880, København 2004 fremstiller begge den danske hegelianisme fyldigt, men har mere øje for den som logisk, metafysisk og religionsfilosofisk tendens end som politisk og historiefilosofisk strømning. De sidstnævnte aspekter af den danske hegelianisme berøres i Bagge Monrad; Grethe Jensen: »Den unge Orla Lehmanns historiesyn «, in Historisk tidsskrift, Vol. 85, bd. 1, 1985, pp. 40-65; Friisberg Ideen; Bertel Nygaard: »Frihed, enhed og historie. Hegelianisme i dansk politisk kultur «, in Slagmark, nr. 50, 2007, pp. 15-29; samme: »Hegelianism in Politics. Denmark 1830-48«, in Intellectual History Review, 2009 (kommende udgivelse). Forbindelser mellem religionsfilosofi og politisk kamp i den tyske hegelianisme understreges i J.E. Toews: Hegelianism: The Path Toward Dialectical Humanism, 1805-1841, Cambridge 1980, og Warren Breckman: Marx, the Young Hegelians and the Origins of Radical Social Theory, Cambridge 1999. Jf. også Hans Jensen: »Den politisk-historiske Udviklingstanke i de danske Forfatningsdrøftelser ", in Historisk Tidsskrift, rk. 10, bd. 5, pp. 431-44.

16 Hegel Werke, 20 bd., Frankfurt a.M. 1970, (herefter $H W$ ) bd. 12, p. 529; HW 7, p. 360; Joachim Ritter: Hegel und die französische Revolution, Frankfurt a.M. 1965 [1957]; Joseph McCarney: Hegel on History, London 2000.

17 H.C.A. Lund: Studenterforeningens Historie 1820-70, 2 bd., København 1896, bd. 2, pp. 1-12; Mourits Mørk Hansen: Livs-erindringer, Åbenrå 1968, p. $49 f$.

18 Jf. Søren Juelstorp: »Den store forfatningsdebat 1841-42 «, in Historie, nr. 1, 1995, pp. 59-80; Dan Charly Christensen: En analyse af hovedpunkter $i$ forfatningsdiskussionen i Danmark 1830-1849 upubl. prisopgave, 1969, pp. 33-100.

19 Jf. Juelstorp »Den store«, p. 6lff, samt Nygaard »Frihed «.

20 Ørsted [anonym] i Tidsskrift for Litteratur og Kritik, vol. 7, 1842, p. 390, $384 f$.

21 Sibbern i Adresseavisen, løbende 28/8-1840 til 17/12-1840. Jf. også J. Himmelstrup: Sibbern. En Monografi, København 1934, især p. 184ff; Erik Schrøder: Frederik Christian Sibbern 1785-1872. Politisk filosof og filosofisk politiker. Et studie i borgerlig bevidsthedsdannelse, upubl. speciale, 1977, især pp. 6074.

22 »Om de attraaede Forandringer i den danske Statsforfatning af P.G. Bang «, in Kjøbenhavnsposten, 26/6-1842.

$23 \mathrm{Om}$ krisebegrebets oprindelse i medicinsk sprogbrug og dets forvandling i forbindelse med en moderne tidserfaring: Otto Brunner m.fl. (red.): Geschichtliche Grundbegriffe, bd. 3, Stuttgart 1982, pp. 617-650.

24 Jf. FpB I, p. 5, og Heiberg Om Philosophiens, p. 17. Den grundigste nyere læsning af Heibergs tekst, i Lasse Horne Kjældgaard: Sjelen efter døden. Guldalderens moderne gennembrud, København 2007, forbigår p. 52 den hegelianske Aufhebung-tanke og de dermed sammenhængende tvetydigheder i dette udtryk ved at læse det alene som en afstandtagen til politiseringen.

25 Jf. også den senere åbne diskussion mellem Heiberg og Monrad: Heiberg: 
»Theatret. Kongen og Bonden«, in Intelligensblade, nr. 39-40 (1. november 1843), især pp. 50-52, 56; Monrad: »Intelligensblade 39-40«, in Fadrelandet $17 / 11-1843$.

26 Monrad »Intelligensblade«, p. 167.

27 Jf. dobbeltheden i det marxistiske (ligeledes hegeliansk baserede) begreb om historisk nødvendighed: Helmut Fleischer: Marxismus und Geschichte, Frankfurt a.M 1969, pp. 142-147.

28 Jens Arup Seip har betegnet noget delvis tilsvarende i dansk-norsk politisk teori i 1700-tallets slutning som 'besværgende' udsagn - »Teorien om det opinionsstyrte enevelde", in Historisk Tidsskrift (norsk), bd. 38, 1958, pp. 397-463, her p. 457f.

29 Jf. også Hegel begreb om 'ophævelse' som enhed af forandring og bevarelse, jf. $H W 5$, pp.113-15.

30 Jf. $F p B$ I, p. 4, samt overgangen fra tredje- til førstepersonsform i forfatterens selvbeskrivelse p. $4 \mathrm{f}$

31 FpB I, p. 9, jf. Monrad »Intelligensblade«, p. 166; Monrad: »Saksiske Tilstande", in samme: Gjengangeren, indeholdende Bidrag til den nyeste Tids Historie, København 1844, p. 8f.

32 Jf. Monrad »Intelligensblade«, p. 166.

33 D.G. Monrad [anonym, som redaktør]: »Nationale Bevægelser«, in Dansk Folkeblad, 30/6-1843.

34 Fem år senere forklarer han dog den konstitutionelle bevægelses foreløbige nederlag (hermed menes vel: siden 1831) med, at den var rent kongelig, hvorimod en fremtidig sejrende konstitutionel bevægelse må være »folkelig «. Manuskript til forelæsning om Danmarks nyere historie, 1844, 14. forelæsning, D.G. Monrads privatarkiv, Rigsarkivet, pk. 3, læg I, D.2.

35 Monrad: "Prof. Sibbern og flyvende politiske Blade Nr. 1 og 2 «, in Fadrelandet, 13/3-1840, sp. 691. Jf. også samme: Den rhinske Landdag og den franske Ret, 2 hæfter, København 1846.

36 Monrad: »Oscar den Første«, in Monrad Gjengangeren, p. 95.

37 Monrad »Prof. Sibbern«, 691; FpB III, p. 15.

38 Når Monrad dog ikke nævner Hegel i sit manifest, er det sandsynligvis fordi han ønsker »at forstaaes af Alle« med henblik på en politisk vækkelse af kredse, der ikke nødvendigvis besidder filosofiske kundskaber. [FpB I, p. 7.]

39 Jf. Frederik Schiern: »Historieskrivningens Udvikling « (1842), in samme: Historiske Studier, bd. 1, København 1856, p. 209, 256; Christian Molbech: »Om Historiens nationale Betydning og Behandling; om historiske Arbeider og Formaalene for en historisk Forening i Danmark «, in Historisk Tidsskrift, I: 1, 1840, pp. 22-26.

40 Tilsvarende afviste han at blive fast skribent på den demokratisk-radikale Kjøbenhavnsposten: D.G. Monrad til A.P. Liunge, 20/2-1840, i Det kongelige Bibliotek, NKS 2631.

41 Typisk for perioden efter den franske revolution bruges de to ord i flæng. Jf. Brunner Geschichtliche, bd. 7, p. 284, 316ff, samt f.eks. FpB III, p. 5, 6: »Folkets Kjerne« og »Nationens Kjerne«. I FpB bruges 'folk' dog langt oftere end det latinsk afledte synonym, muligvis for at gøre fremstillingen mere 'dansk'.

42 Parallellen til J.L. Heibergs kritik af 'massernes' atomisering i modsætning til det organiske 'folk' er slående. Jf. f.eks. Heiberg: »Folk og Publicum«, in 
Intelligensblade, nr. 6 (1. juni 1842).

43 Jf. Brunner Geschichtliche, bd. 4, pp. 413-67; samt f.eks. Tage Algreen-Ussings sammenkædning af almenånd og offentlighed som åbenhed: »[D]et er ved Pressen, og først og fornemmelig ved den, at Almenaanden skal oplives." »Om Almeenaandens Oplivelse«, in Dagen 27/12-1834.

44 Jf. Brunner Geschichtliche, bd. 7, pp. 144-49, 314-37

45 Fx. III: 3; I: 25-30. Jf. til periodens nationalisme f.eks. E.J. Hobsbawm: Nations and Nationalism Since 1780: Programme, Myth, Reality, Cambridge 1997 [1990], pp. 18-45; Ole Feldbæk (red.): Dansk identitetshistorie 2: Et yndigt land, København 1991, p. 325ff, især pp. 328, 368-87.

46 Monrad: 'Nationale Bevægelser', p. 53.

47 Henrik Horstbøll: »Civilisation og Nation 1760-1830«, i Søren Mørch, red.: Danmarks historie, bd. 10: Historiens historie, København: Gyldendal, 1990, pp. 176-79; Jensen »Lehmann«; Grethe Jensen: Den unge Orla Lehmann, upubl. licentiatafhandling, 1989, pp. 50-54; C.F. Allen: Haandbog i Fadrelandets Historie med stadigt Henblik paa Folkets og Statens indre Udvikling, København 1840; Grethe Jensen: Historikeren C.F. Allens forfatterskab, upubl. speciale, 1982, p. 17; Bertel Nygaard: »Civilisation, kamp og fremskridt i C.F. Allens Haandbog i Fadrelandets Historie ", in Historie, nr. 1, 2009 (kommende udgivelse).

48 Jf. også FpB I, p. 22: »Frihedsfølelsen og Folkebevidstheden«; samt Monrad »Prof. Sibbern «, sp. 691 om 'menneskebevidsthedens' forvandling til 'folkebevidsthed', der i sammenhæng med det ovenfor citerede udsagn om 'folket', der skal blive 'mennesker' og 'borgere' antyder en dialektisk opfattelse af forholdet mellem folk og menneskehed.

49 Jf. tilsvarende i Carl Weis: »Om Statens historiske Udvikling «, in Perseus. Journal for den speculative Idee, no. 2, 1838, p. $96 f$.

50 Jf. f.eks. Sibbern i Adresseavisen, 3/10-1840 med kritikken af ham i f.eks. »Maae vi ikke skamme os? ", in Fedrelandet 15/9-1840 og »Hr. Professor Sibbern eller den politiske Fanatismes Reaction «, in Kjøbenhavnsposten 9/101840 \& 5/11-1840; N.F.S. Grundtvig: Politiske Betragtninger med Blik paa Danmark og Holsteen, København 1831; J.C. Lindberg: »Kjøbenhavn 1660 og 1840«, in Adresseavisen 17/8-1840; Himmelstrup Sibbern; Schrøder Sibbern; Kaj Baagø: Magister Jacob Christian Lindberg, København 1958, pp. 346-357.

51 Henrik Hertz: Stemninger og Tilstande. Scener og Skildringer af et Ophold $i$ Kjøbenhavn, København 1839, p. 217, 226, 256;-2123-(Peder Hjort): »Af et Brev (som virkelig er kommet) fra Provindserne", in Kjøbenhavns flypende Post 1835, nr. 58; Søren Kierkegaard: »Vor Journal-Litteratur. Studium efter Naturen i Middagsbelysning. Foredrag, holdt i Studenterforeningen d. 28. Novb. 1835 ", in Niels Thulstrup (red.): Søren Kierkegaards Papirer, bd. 1, København 1968, p. 173.

52 Begreberne præciseres i Monrad: »Den russiske Prindsesse", in Monrad Gjengangeren, p. 127. Jf. også Monrad 'Oscar den Første', p. 101.

53 Jf. det samme budskab i mere generelle vendinger i Monrad »Den russiske Prindsesse«(Gjengangeren), p. 122.

54 Povl Bagges bemærkning, at Monrad i 1848 ville benytte den almindelige valgret »i konservatismens tjeneste « viser vist en tilsvarende betragtning af et konservativt element. [Bagge Monrad, p. 165f]. Claus Friisbergs tolkning af 
Bagges udsagn som en helhedskarakteristik af Monrads 'konservative' og hans kritik af, at denne analyse bunder i senere tiders konservatismeforståelser, ser bort fra, at begrebet 'konservativ' omkring 1848 ikke kun fik den negative afgrænsningsfunktion, som ekspliciteres i $F p B$, men blev også blev udbredt som positivt begreb i legitimeringen af moderat liberale reformstandpunkter. Jf. Friisberg »Monrads«, p. 216f.; Niels Clemmensen: »Fra Junigrundlov til revideret Junigrundlov 1849-1866", in Den jyske historiker nr. 83-84, 1999, især pp. 185-90.

55 Jf. Nygaard »Civilisation«.

56 Jf. også den ovenfor nævnte betydningsglidning fra Europa til det enkelte land i skildringen af statens udvikling. Kritikken af provinsialismen ud fra et dobbelt åbent nationalitets- eller folkebegreb har desuden, som andre træk i Monrads tænkning, paralleller hos hegelianeren Heiberg, jf. den sidstes » Det Nationale og det Provindsielle«, in Intelligensblade nr. 15 (15/10-1842).

57 Jf. også Monrad: »Oscar den Første «, in Monrad Gjengangeren, p. 103, 105; samme: Nogle Bemarkninger om det skandinaviske Selskab, København 1844.

58 Om skandinavismen: Henrik Becker-Christensen: Skandinaviske drømme og politiske realiteter 1830-1850, Århus 1981. Jf. også John Sanness: Patrioter, intelligens og skandinaver: Norske reaksjoner på skandinavismen for 1848, Oslo 1959; Åke Holmberg: Skandinavismen i Sverige vid 1800-talets mitt (18431863), Göteborg 1946.

59 Heiberg »Et Par Bemærkninger«; Kierkegaard »Vor Journal-Litteratur«, pp. 157-178; Hertz Stemninger, p. 217, 241 og passim.

60 Det blev i samtiden diskuteret, om trykkefrihedsbegrænsningerne virkelig indebar egentlig censur. A.S. Ørsted argumenterede grundigt for, at der ikke var tale om censur, og dele af den liberale bevægelse, navnlig Tage AlgreenUssing, opfordrede til, at den liberale presse tog ham på ordet og begyndte at skrive friere under visheden om, at enhver trykkefrihedstvist i sidste ende skulle for en uvildig domstol. [A.S. Ørsted: »Forsøg til en rigtig Fortolkning og Bedømmelse over Forordningen om Trykkefrihedens Grændser, dateret den 27de September 1799. Første Deel «, in samme: Arbejder om Trykkefribeden, København 1947, pp. 25-152. Tage Algreen-Ussing: »Om Trykkefriheden i Danmark «, in Dagen 17/2-1834ff.] Andre liberale insisterede dog på, at trykkefrihedsbegrænsningerne indebar censur, om ikke i streng juridisk forstand, så i praksis. Jf. Juelstorp »Den københavnske intelligens «, der er skrevet ud fra erklæret sympati med den sidstnævnte fløj, samt Jørgensen Trykkefrihedsspørgsmaalet.

61 Aristokrati og Demokrati«, in Fedrelandet, 25-27/3-1843; samt Monrads og Hother Hages udgivelse på dansk af uddrag af Tocquevilles La démocratie en Amérique - in Monrad Gjengangeren, p. 14lff.

62 »Aristokrati«, 27/3-1843. Jf. Alexis de Tocqueville: De la démocratie en Amérique, 2 bd., Paris 1961, her bd. 2, pp. 328-35 (del 4, kap. 7). Traditionen for at forstå den liberale bevægelse som mere eller mindre lineær optakt til det senere demokrati er så stærk, at selv undersøgelser af politiske tanker i enevældens sidste årtier, der generelt er nuancerende, forveksler de liberales tanker om et konstitutionelt demokrati for de dannede med 'demokrati'. Jf. f.eks. Friisberg Ideen, s 336, 337, 344; samt Friisberg »Monrads«, p. 228, der i Monrads fordring om teologens, juristens og medicinerens politiske deltagelse, ser »et kernepunkt i den demokratiske tankegang «, nemlig at »folk « 
kan deltage i politik. Her forveksles således Monrads udsagn om den dannede folkets kernes politiske deltagelse med en forestilling om folkets deltagelse som helhed.

63 Den 'rå, udannede/uoplyste masse' var en fast ekskluderende vending hos datidens liberale, jf. også C.F. Allen til Laurids Skau, 18. januar 1846 in H.V. Gregersen (red.): Laurids Skaus brevveksling med politiske venner $i$ København, København 1966, p. 40; C.N. David [anonym]: »Breve til en Politicus paa Landet «, in Kjøbenhavns flyvende Post 1830, nr. 99. Dette lå i forlængelse af 1700-talstanker om forholdet mellem de oplyste og de ikke-oplyste, jf. f.eks. Juliane Engelhardt: De patriotiske selskaber $i$ den danske helstat 1769-1814. Borgerskab, foreningssociologi og statstenkning, upubl. ph.d.-afhandling, 2004, pp. 359-74, 378.

64 Monrad: »Den russiske Prindsesse og det skandinaviske Samfund. V«, in Dansk Folkeblad 1/9-1843, p. 107.

65 Jf. tilsvarende hos Orla Lehmann [under mærke]: »F.A. Holstein, Om Provindsialstænder «, in Maanedsskrift for Litteratur, vol. 7, 1832, p. 156f; Otto Müller: Om Valgret og Valgbarhed med sordeles Hensyn til de danske Provindsialstender, København 1842, p. 100.

66 Jf. Monrad: Politiske Breve, nr. 14-18. Liberalismens Gjenmole til Biskop Martensens sociale Ethik, Nykøbing Falster 1878, pp. 81f.

67 Jf. f.eks. Jensen Den unge Lehmann, pp. 235-27, 240, 248f, 253.

68 Jf. f.eks. »Politiske Kritiker. Ditlev Gothard Monrad«, in Nord og Syd, bd. 2, pp. 53-65.

69 Jean-Jacques Rousseau: Du contrat social, især bog II, kap. 3. Jf. Friisberg Ideen, p. 320f, 67.

70 Jf. Tidende for Forhandlinger ved Provindsialstanderne for Sjallands, Fyens og Lollands=Falsters Stifter samt for Island og Foröerne, nr. 53 og 54, 1. februar 1836, sp. 859f; E.C. Tryde: »Hvor er Kernen i Folket? «, in Dansk Folkeblad, vol. 2 , nr. 2 \& 3, 8. april 1836; Ras.: »Har Hs. H. Hr. Provst Tryde eller Hr. Skibsklarerer Gad fundet Kjernen i Folket. «, in Kjøbenhavnsposten 22/7 1836; K. Gad: »Hvor er Skallen af Folket? «, in Kjøbenhavnsposten 13/6 1836. Bagge Monrad, p. 29, ser i Monrads åbning af middelstandsbegrebet over for embedsstanden en tilknytning til Hegels middelstandsbegreb snarere end »det liberale vesteuropæiske«, til hvilket Bagge regner Guizot. Den danske debat viser imidlertid, at inklusionen af embedsstanden i bestemmelsen ikke nødvendigvis er noget lån fra Hegel. Som bemærket ovenfor, var en sammentænkning af hegelianisme og fransk liberal historieforståelse dog også ret udbredt.

71 Jf. f.eks. Allen Haandbog.

72 Bagge Monrad, p. 25. Jf. $H W 7$, samt kritikken af den britiske repræsentationsform i $H W 11$, p. 107.

73 Jf. Eduard Gans: Naturrecht und Universalrechtsgeschichte, Stuttgart 1981 [1840], p. 81ff, 103.

74 P. A. Tutein: »Om de constitutionelle Bestræbelsers Værd og Betydning «, in Dansk Ugeskrift, 2. række, 1. bind, 1842, pp. 1-72. Dette skrift var hovedemnet for $F p B$ III.

75 Sibbern »Magister Monrads«, her 8/3-1840.

76 Jf. F.C. Sibbern: Meddelelser af Indholdet af et Skrift fra Aar 2135, 2 bd., København 1858-72.

77 Det klassiske værk om dette emne, Jürgen Habermas: Strukturwandel der 
Bertel Nygaard: »D.G. Monrads liberale manifest fra 1839«

Öffentlichkeit, Neuwied \& Berlin 1962, antyder denne pluralisering af offentligheder, der dog først er blevet udfordret i en mangfoldighed af senere historiske undersøgelser af især tysk, fransk og engelsk historie. 